\title{
Electrochemical Behavior of the Tris(Pyridine)-Cu Funnel Complexes : an Overall Induced-Fit Process Involving an Entatic State through a Supramolecular Stress
}

\author{
Nicolas Le Poul, ${ }^{\dagger}$ Morgan Campion, ${ }^{\dagger}$ Guillaume Izzet,${ }^{\ddagger}$ Bénédicte Douziech,${ }^{\dagger}$ Olivia \\ Reinaud, ${ }^{+}$and Yves Le Mest ${ }^{*, \dagger}$ \\ Laboratoire de Chimie, Electrochimie Moléculaires et Chimie Analytique, UMR CNRS 6521, Université \\ de Bretagne Occidentale, 6 av. Le Gorgeu, 29238 Brest cedex 3, France, and Laboratoire de Chimie et \\ Biochimie Pharmacologiques et Toxicologiques, UMR CNRS 8601, Université René Descartes, 45 rue \\ des Saints Pères, 75270 Paris cedex 06, France.
}

\section{Supplementary materials}

Safety note: Caution ! Although we have not encountered any problem, it is noted that perchlorate salts of metal complexes with organic ligands are potentially explosive and should be handled only in small quantities with appropriate precautions.

$\left[\mathbf{C u}\left(\mathbf{X}_{6} \mathbf{M e}_{3} \mathbf{P i c}_{3}\right)\left(\mathbf{H}_{2} \mathbf{O}\right)_{2}\right]\left(\mathbf{C l O}_{4}\right)_{2}$ : To a solution of $\mathrm{Cu}\left(\mathrm{ClO}_{4}\right)_{2}\left(\mathrm{H}_{2} \mathrm{O}\right)_{6}(14.4 \mathrm{mg} ; 38.8 \mu \mathrm{mol})$ in acetone $(4 \mathrm{~mL})$ was added a stoechiometric amount of the ligand $\mathrm{X}_{6} \mathrm{Me}_{3} \mathrm{Pic}_{3}(50 \mathrm{mg} ; 38.8 \mu \mathrm{mol})$. The green homogeneous mixture was stirred for one hour, concentrated to $2 \mathrm{~mL}$, filtered on celite and precipitated with pentane. The resulting green solid was separated from the solvent and dried under vacuum $(50 \mathrm{mg})$. Yield: $84 \%$ - IR $\left(\mathrm{cm}^{-1}\right)(\mathrm{KBr}): 2961 ; 1610 ; 1600 ; 1580 ; 1125-1090 ; 623\left(\mathrm{ClO}_{4}\right)$. UV-Vis $(\mathrm{MeCN}): 400 \mathrm{~nm}(\mathrm{sh})\left(300 \mathrm{M}^{-1} \mathrm{~cm}^{-1}\right), 727 \mathrm{~nm}\left(\varepsilon=90 \mathrm{M}^{-1} \mathrm{~cm}^{-1}\right)-\mathbf{R P E}\left(\mathrm{CH}_{2} \mathrm{Cl}_{2} / \mathrm{MeCN}\right) 100 \mathrm{~K}: \mathrm{g}_{\perp}=2,07, \mathrm{~g}_{/ /}=$ $2,34\left(\mathrm{~A}_{/ /}=148 \mathrm{G}\right)$.

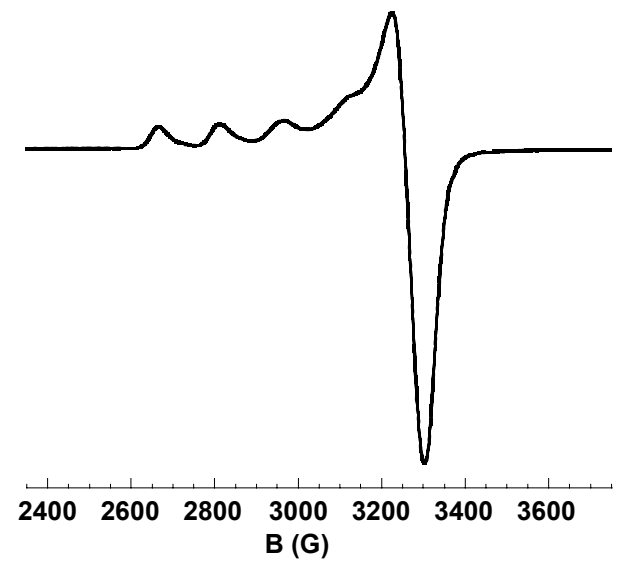

Figure S1. EPR spectrum (X band, $100 \mathrm{~K}$ ) of $\left[\mathrm{Cu}\left(\mathrm{X}_{6} \mathrm{Me}_{3} \mathrm{Pic}_{3}\right)(\mathrm{MeCN})\left(\mathrm{H}_{2} \mathrm{O}\right)\right]\left(\mathrm{ClO}_{4}\right)_{2}$ in $\mathrm{CH}_{2} \mathrm{Cl}_{2} / \mathrm{MeCN}(1: 1)$.

Experimental electrochemistry

The electrochemical studies of the copper complexes have been performed in a glovebox (Jacomex) $\left(\mathrm{O}_{2}<1\right.$ ppm, $\mathrm{H}_{2} \mathrm{O}<1$ ppm) with a home-designed 3-electrodes cell (WE: Pt, RE: Ag, CE: Cu). The potential of the cell was controlled by an AUTOLAB PGSTAT 100 (Ecochemie) potentiostat monitored by a computer. All solvents used $\left(\mathrm{CH}_{2} \mathrm{Cl}_{2}, \mathrm{THF}, \mathrm{CH}_{3} \mathrm{CN}\right.$, $\mathrm{PhCN}, \mathrm{DMF}$ ) have been distilled and kept under $\mathrm{N}_{2}$. The supporting salt, $\mathrm{NBu}_{4} \mathrm{PF}_{6}$, has been purified, dried under vacuum for 48 hours at $100^{\circ} \mathrm{C}$, then kept under $\mathrm{N}_{2}$ in the glovebox. All experiments have been performed with solutions of $10^{-3} \mathrm{M}$ in electroactive species. It has been checked that the behavior was not different for different values of concentration $\left(510^{-4} \mathrm{M} \leq\right.$ $C \leq 310^{-3} \mathrm{M}$ ). The experimentally measured ohmic drop (current interrupt method) was included in the simulation procedure as uncompensated solution resistance.

\section{Simulation procedure}

The voltammograms have been simulated with a first-order reaction approximation. Although the coordination number of the studied compounds is not invariant during the electron transfer process, the ligand exchange has been neglected in terms of kinetics and the conformational rearrangement considered as the limiting process. The fits have been performed with the Digisim 3.1 software $^{\circledR}$ using a double $\mathrm{C}_{\mathrm{rev}} \mathrm{E}$ approximation as the reference mechanism (the electrochemical reactions are based on Butler-Volmer kinetics). The confidence level for all varying parameters is superior to $68.3 \%$. Diffusion coefficients have been estimated at $510^{-7} \mathrm{~cm}^{2} \mathrm{~s}^{-1}$. Surface area $\left(0.024 \mathrm{~cm}^{2}\right)$ was determined by previous electrochemical experiments. The redox potentials in both geometries, $E_{\mathrm{A}}^{\circ}$ and $E^{\circ}{ }_{\mathrm{B}}$, were extracted from the experimental CVs. Uncompensated resistance $(100 \Omega)$ and double-layer capacitance $(0.8 \mu \mathrm{F})$ have been incorporated in the fits calculations. The best fits between the experimental and simulated sets of curves have been obtained when fixing the symmetry coefficient $\alpha$ to 0.62 for the $\mathrm{Cu}(\mathrm{II}) / \mathrm{Cu}(\mathrm{I})_{\mathrm{Td}}$ system, and 0.28 for the $\mathrm{Cu}(\mathrm{II}) / \mathrm{Cu}(\mathrm{I})_{\mathrm{SBP}}$ system. Preliminary simulations were performed to verify that the value of this parameter $(0.1<\alpha<0.9)$ did not affect significantly the thermodynamic and kinetics $K$ and $k$ values. The "non-ideal" values $(\neq 0.5)$ obtained for $\alpha$ indicate that the reduction process is kinetically favored in the SBP geometry $(\alpha=0.28)$ and slightly disfavored in the Td configuration $(\alpha=0.62)$. The asymmetry of the heterogeneous electron transfer kinetics, which is specific to our supramolecular system, may be ascribed to a difference in solvent reorganization energy

\footnotetext{
${ }^{\dagger}$ Université de Bretagne Occidentale.

‡Université René Descartes.
} 
owing to the reduction or oxidation step. Particularly, this solvent effect seems important for the complex in the SBP configuration : our hypothesis is that the electroactive copper site in this conformation is very sensitive to solvent reorganization via the external ligand sitting on the top of the metal. In the case of the Td geometry, this effect is lower since the copper is totally encapsulated and isolated from the electrolyte solution. A new generation of totally encapsulated $\mathrm{Cu}$ (II) and $\mathrm{Cu}(\mathrm{I})$ complexes could be of interest to unravel this very interesting issue. ${ }^{1}$

\section{Simulation results}

The adequacy of the model proposed by Rorabacher et col. ${ }^{2}$ to the present case allowed to apply a simulation procedure of the CVs using the Digisim ${ }^{B}$ program to evaluate the kinetics and thermodynamics of the redox process associated to the tris(pyridine) complexes in MeCN. The Figures S2 (b) and S2 (d) display the simulated CVs respectively obtained for the $\mathrm{Cu}(\mathrm{II})$ and $\mathrm{Cu}(\mathrm{I})$ complexes at different scan rates $\left(0.01 \mathrm{~V} \mathrm{~s}^{-1} \leq v \leq 1 \mathrm{~V} \mathrm{~s}^{-1}\right)$. The appearance of these voltammograms satisfactorily reproduces the trends seen in the experimental curves for the $\mathrm{Cu}$ (II) (see Figure S2 (a)) and $\mathrm{Cu}(\mathrm{I})$ (see Figure S2 (c)) tris(pyridine) solutions. ${ }^{2 a}$ The resulting parameters are listed in Table S1. It has been verified that the slight discrepancies between $\mathrm{Cu}(\mathrm{I})$ and $\mathrm{Cu}(\mathrm{II})$ data sets do not result from any experimental artifact. This difference might result from the simplified square scheme model considered for this redox process (a first order approximation) which does not take into account all the kinetic perturbations (homogeneous and heterogeneous) due for example either to the kinetics of side reactions such as the external ligand exchange or heterogeneous aspects specific to the present compounds discussed above. The high value obtained for the thermodynamic chemical constant $K_{1}\left(K_{1}=k_{1} / k_{-1} \approx 310^{5}\right)$ indicates that the $\mathrm{Cu}(\mathrm{I})$ ion is highly unstable in the SBP conformation. This is also evidenced by the absence of the oxidation peak $E_{\mathrm{pa}}{ }^{\mathrm{A}}$ at low scan rates on the $\mathrm{Cu}$ (II) cyclic voltammogram (see Figures S2 (a) and S2 (c)). On the other hand, the value obtained for the thermodynamic constant $K_{2}\left(K_{2}=k_{2} / k_{-2}=0.07\right)$ shows that the $\mathrm{Cu}(\mathrm{II})$ complex can exist as an equilibrium between the two geometries, Td and SBP. This is clearly characterized on the experimental CVs by the presence of two reduction peaks $\left(E_{\mathrm{pc}}{ }^{\mathrm{A}}\right.$ and $\left.E_{\mathrm{pc}}{ }^{\mathrm{B}}\right)$ at high scan rates.
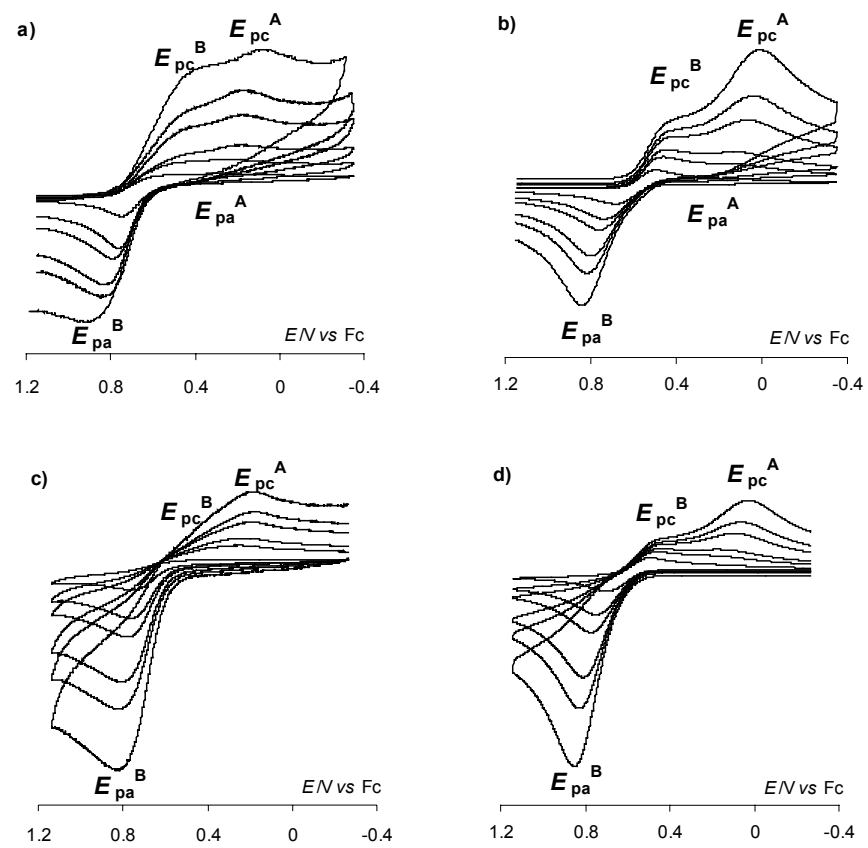

Figures S2 (a) and S2 (c). Experimental $\mathrm{CVs}$ of the $\mathrm{Cu}(\mathrm{II})$ and $\mathrm{Cu}(\mathrm{I})$ complexes of the $\mathrm{X}_{6} \mathrm{Me}_{3} \mathrm{Pic}_{3}$ ligand in $\mathrm{CH}_{3} \mathrm{CN} /$ $\mathrm{NBu}_{4} \mathrm{PF}_{6} 0.2 \mathrm{M}, C=10^{-3} \mathrm{M}$ (working electrode: Pt; reference: $\mathrm{Fc}^{+} / \mathrm{Fc}$ system) at $v=0.01 ; 0.05 ; 0.1 ; 0.3 ; 0.5 ; 1 \mathrm{~V} \mathrm{~s}^{-1}, T=293 \mathrm{~K}$. Figures S2 (b) and S2 (d). Simulated CVs of the $\mathrm{Cu}(\mathrm{II})$ and $\mathrm{Cu}(\mathrm{I})$ complexes.

Table S1. Thermodynamic and kinetic parameters obtained from the fitting of $\mathrm{CVs}$ for the $\mathrm{Cu}(\mathrm{II})$ and $\mathrm{Cu}(\mathrm{I})$ derivatives.

\begin{tabular}{ccccccccccc}
\hline $\begin{array}{c}\text { Bulk } \\
\text { species }\end{array}$ & $\boldsymbol{E}_{\mathrm{A}}^{\mathbf{0}} / \mathbf{V}$ & $\boldsymbol{E}_{\mathrm{B}}^{\mathbf{0}} / \mathbf{V}$ & $\boldsymbol{K}_{\mathbf{1}}$ & $\boldsymbol{K}_{\mathbf{2}}$ & $\boldsymbol{k}_{\mathbf{A}}^{\mathbf{0}} / \mathbf{c m ~ s}^{-\mathbf{1}}$ & $\boldsymbol{k}_{\mathbf{B}}^{\mathbf{0}} / \mathbf{c m ~ s}^{-\mathbf{1}}$ & $\boldsymbol{k}_{\mathbf{1}} / \mathbf{s}^{-\mathbf{1}}$ & $\boldsymbol{k}_{\mathbf{- 1}} / \mathbf{s}^{-1}$ & $\boldsymbol{k}_{\mathbf{2}} / \mathbf{s}^{-1}$ & $\boldsymbol{k}_{\mathbf{- 2}} / \mathbf{s}^{-1}$ \\
\hline $\mathrm{Cu}(\mathrm{II})$ & 0.65 & 0.26 & $410^{5}$ & 0.08 & $310^{-4}$ & $310^{-4}$ & $210^{3}$ & $4.910^{-3}$ & 8 & 100 \\
$\mathrm{Cu}(\mathrm{I})$ & 0.65 & 0.26 & $310^{5}$ & 0.06 & $310^{-4}$ & $310^{-4}$ & 312 & $110^{-3}$ & 5 & 83 \\
\hline
\end{tabular}

\footnotetext{
${ }^{1}$ Izzet, G.; Douziech, B.; Prangé, T.; Tomas, A.; Jabin, I.; Le Mest, Y.; Reinaud, O. submitted to Proc. Natl. Acad. Sci. U.S.A.

${ }^{2}$ (a) Bernardo, M. M.; Robandt, P. V.; Schroeder, R. R.; Rorabacher, D. B. J. Am. Chem. Soc. 1989, 111, 1224. (b) Villeneuve, N. M.; Schroeder, R. R.; Ochrymowycz, L. A.; Rorabacher, D. B. Inorg. Chem. 1997, 36, 4475.
} 